\title{
Mengkaji Konsep Desain Generatif Dalam Dunia Konstruksi Kontemporer Pada Bangunan Great Court Di London
}

${ }^{1}$ Rustama Fasda Bimatukmaru, ${ }^{2}$ Ashadi

${ }^{1}$ Program Studi Arsitektur Fakultas Teknik Universitas Muhammadiyah Jakarta, ${ }^{2}$ Program Studi

Arsitektur Fakultas Teknik Universitas Muhammadiyah Jakarta

2018460050@ftumj.ac.id

\section{Informasi Naskah}

Diterima: 26/10/2021; Disetujui terbit: 2/12/2021; Diterbitkan: 31/12/2021;

http://journal.uib.ac.id/index.php/jad

\begin{abstract}
ABSTRAK
Bangunan Great Court merupakan bangunan bergaya kontemporer yang diduga menerapkan konsep generatif pada konstruksinya. Tujuan penelitian ini untuk memahami konsep desain generatif dalam dunia konstruksi kontemporer, terhadap karakteristik dan penerapan pada bangunan Great Court. Melalui metode kualitatif dan pendekatan deskriptif pada penelitian ini untuk memperoleh pengetahuan terhadap konsep generatif dalam dunia konstruksi kontemporer, terhadap studi kasus bangunan Great Court. Bangunan Great Court memiliki karakteristik dari ciri konsep generatif terhadap elemen konstruksi bangunan. Hasil penelitian ini menunjukkan bahwa konsep generatif terhadap konstruksi kontemporer memiliki beberapa prinsip yang ada pada bangunan, seperti bentuk yang rumit dan kompleks; bentuk yang unity; bentuk yang dinamis; bentuk geometri lengkung yang kompleks; dan bentuk pengulangan dan simetri.
\end{abstract}

Kata Kunci: Desain Generatif, Konstruksi, Kontemporer, Great Court

\begin{abstract}
The Great Court building is a contemporary-style building that is thought to have applied the generative concept to its construction. The purpose of this research is to understand the generative design concept in the contemporary construction world, to the characteristics and application of the Great Court building. Through qualitative methods and descriptive approaches in this study to gain knowledge of generative concepts in the world of contemporary construction, to case studies of the Great Court building. The Great Court building has the characteristics of a generative concept characteristic of building construction elements. The results of this study indicate that the generative concept of contemporary construction has several principles that exist in buildings, such as complex and complex shapes; a unified form; dynamic form; complex curved geometric shapes; and forms of repetition and symmetry.
\end{abstract}




\section{PENDAHULUAN}

Dunia arsitektur memiliki perkembangan yang sangat pesat terutama dalam hal mendesain suatu bangunan serta fungsi ruang secara kompleks, salah satu metode yang sering digunakan adalah metode desain generatif. Desain generatif membantu arsitek dalam memanfaatkan potensi komputasi untuk mengeksplorasi solusi yang jauh lebih luas daripada yang dilakukan dengan metode desain tradisional. Desain generatif tidak memiliki intuisi atau bias yang melekat untuk memecahkan masalah tertentu, oleh karena itu desain-desain generatif dapat membantu arsitek membebaskan diri pengucapan yang ditemukan dalam proses desain tradisional, yang mengarah pada penemuan solusi desain berkinerja tinggi tetapi juga solusi baru dalam mendesain.

Di dalam ilmu metode desain mutakhir, metode generatif menjadi bagian dari pendekatan parametrik. Dengan pendekatan parametrik, arsitek ataupun desainer dapat menganalisa kemungkinan-kemungkinan deformasi geometri dengan cepat. Pada tahap analisis, arsitek dapat langsung secara interaktif melihat kemungkinan-kemungkinan penyelesaian sebuah desain sehingga arsitek dapat akurat dengan menentukan arahan penyelesaian desain. Pendekatan parametrik juga memungkinkan arsitek untuk langsung memfabrikasi elemenelemen bangunan dengan menggunakan teknologi, sehingga mengefisienkan pemakaian material yang akan digunakan pada desain sekaligus mempercepat proses konstruksi (Atthaillah, 2014). Dengan pendekatan parametrik, arsitek ataupun desainer dapat menganalisa kemungkinan-kemungkinan deformasi geometri dengan cepat. Pada tahap analisis, arsitek dapat langsung secara interaktif melihat kemungkinan-kemungkinan penyelesaian sebuah desain sehingga arsitek dapat akurat dengan menentukan arahan penyelesaian desain.

Algoritma Generatif adalah cara algoritmik dan Parametrik atau Asosiatif untuk menangani geometri dalam masalah desain (Khabazi, 2010). Pernyataan Khabazi tentang desain generatif dibuat menjadi contoh dalam mempermudah menganalisis, mengeksplorasi, dan membuat desain terhadap geometri komputasi terhadap sejumlah besar data, angka, dan perhitungan dalam desain. Dengan adanya bentuk bangunan yang memiliki bentuk tidak biasa dari dasarnya menambah nilai kemajuan dalam merancang pada sebuah ide rancangan desain, sehingga meningkatkan pusat sejarah dan karakteristik suatu tempat dengan adanya bangunan yang unik. Penerapan metode generatif tersebut terlihat dari beberapa bangunan kontemporer yang di bangun oleh arsitek-arsitek ternama seperti, Great Court, karya Foster dan Partners yang diduga menggunakan desain generatif berdasarkan sumber tertulis (Kaarwan, 2021). Bangunan berlokasi di Great Russell St, London WC1B 3DG, United Kingdom (Gambar 1). 


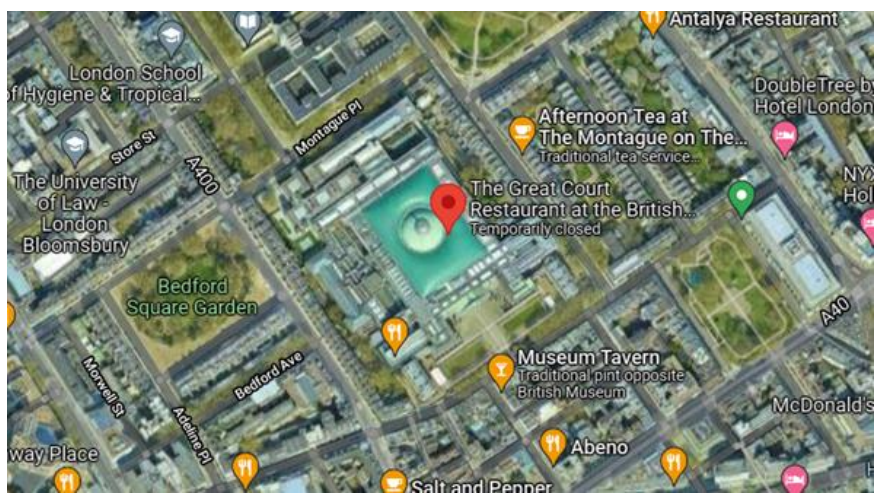

Gambar 1Tampak satelit Great Court

Sumber: https://www.google.com/maps

Berdasarkan uraian diatas penelitian ini mencoba mengeksplorasi bentuk bangunan kontemporer dengan metode konsep generatif. Penerapan dan pendekatan metode generatif pada desain bangunan kontemporer tidak hanya memberi ruang untuk mempermudah menerjemahkan bentuk-bentuk kompleks.

\section{Kajian Pustaka \\ Konsep Desain Generatif}

Dalam merancang suatu rancangan desain arsitektur harus memiliki sebuah konsep atau tema yang melatarbelakangi arsitek dalam merancang. Merancang dalam konteks arsitektur adalah dengan mengubah yang awalnya tidak ada menjadi ada dan mengubah sesuatu yang sudah ada menjadi sesuatu yang lebih baik. Arsitektur merupakan suatu ilmu atau studi yang berkaitan dengan seputar merancang bangunan. Seiring perkembangan dari masa ke masa maka teori serta konsep arsitektur akan semakin berkembang terkait gaya atau aliran dari Arsitektur itu sendiri.

Arsitektur tidak memilah bagian-bagian, tetapi memadukan dan menggabungkan berbagai macam unsur dalam cara baru dan keadaan baru. Arsitektur dapat menciptakan reaksi psikologis terhadap ruang yang dapat dijelaskan dari segi teori fisiologi manusia, struktur, dan bentuk melalui indera penglihatan dan perasa manusia terhadap ruang dan bangunan. Dalam arsitektur, suatu konsep juga mengidentifikasi bagaimana berbagai aspek persyaratan untuk suatu bangunan dapat dipersatukan dalam suatu pemikiran spesifik yang langsung mempengaruhi rancangan dan konfigurasinya (Snyder. \& Catanese, 1991).

Salah satu metode desain yang berkembang belakangan ini adalah desain parametrik. Menurut Artha (2011), yang diacu oleh Aqli, Desain parametrik atau pemodelan parametrik adalah sebuah proses yang didasari pola berfikir atau logika matematika algoritma yang memungkinkan diolahnya bentuk-bentuk yang kompleks pada sebuah struktur atau rancangan bangunan (Aqli, 2015). Salah satu bagian dari desain parametrik adalah konsep generatif. Konsep generatif merupakan proses yang memungkinkan arsitek untuk mengeksplorasi solusi yang lebih luas dengan lebih banyak kemungkinan dan kreativitas; ia menggunakan aturan yang ditentukan parametrik untuk menghasilkan solusi yang kompleks. Desain generatif membuat nama dalam dunia konstruksi kontemporer yang mempengaruhi kemajuan masa depan dalam ilmu arsitektur.

Agkathidis (2015) menyebutkan bahwa pada abad kedua puluh banyak arsitek, insinyur, 
dan desain visioner yang menerapkan metode desain yang sangat mirip dengan pendekatan komputasi saat ini. Sehingga desain generatif menjadikan teknik penemuan yang sudah dikembangkan jauh sebelum revolusi digital. Desain generatif memberikan keterkaitan hubungan antara bentuk dan representasi yang mendukung kompleksitas yang dihasilkan secara komputasi.

Proses generatif digunakan untuk memecahkan masalah tertentu yang kompleks dari suatu desain. Dalam proses desain generatif seorang perancang mengawali dengan sebuah ide, namun kemudian mulai berfikir bagaimana menerjemahkan ide tersebut ke dalam seperangkat aturan (Khidmat, Ulum, Lestari, \& Fukuda, 2020). Konsep desain generatif mengarah terhadap praktik desain yang mana seorang perancang menggunakan program sistem komputer, untuk menghasilkan solusi terhadap masalah desain dengan beberapa tingkat keleluasaan pada konstruksi.

Generatif juga memberikan kemudahan pada perancang melalui proses pembuatan model dan solusi alternatif, tetapi sistem tersebut adakalanya mengalami kesulitan dalam memenuhi persyaratan yang diperlukan dalam merancang. Proses generatif perancangan mampu menghubungkan pola perilaku geometris dan sifat kinerja sistem (Sepehr, Goudling, Rahimian, \& Ganah, 2013) (Gambar 2).

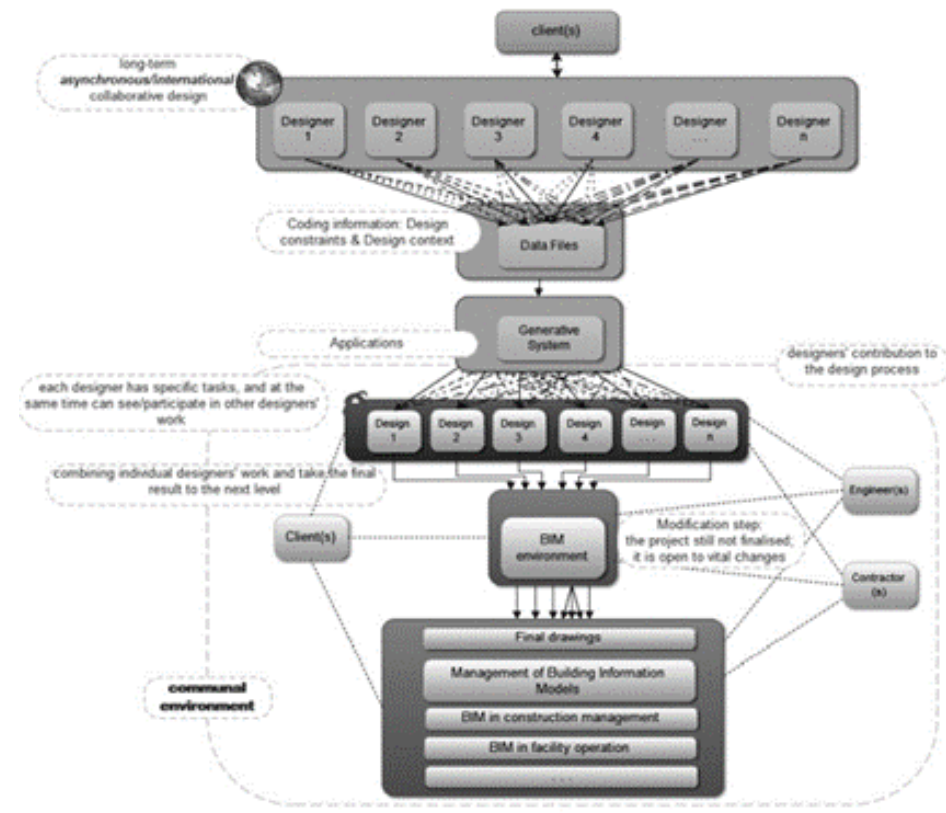

Gambar 2Pola perilaku geometris dan sifat kinerja sistem generatif sumber: Sepehr, dkk, 2013

Desain generatif merupakan suatu proses untuk eksplorasi suatu desain yang dilakukan oleh desainer atau perancang dengan dibatasi secara metode parametrik beroperasi secara terstruktur untuk mendukung desain sebagai proses yang ingin diciptakan. Krish (2011) menjelaskan terdapat tiga proses komponen-komponen dalam mendesain generatif untuk mendesain parametrik dan prosedural yaitu:

1. Skema desain;

2. Sarana untuk menciptakan variasi;

3. Sarana untuk memilih hasil yang diinginkan; 
Dalam pernyataan Calestino Soddu (1994) pada kutipan Agkathidis (Agkathidis, 2015) mendefinisikan desain generatif sebagai "proses morfogenetik menggunakan algoritma yang terstruktur sebagai sistem non-linier untuk hasil unik dan tidak dapat diulang tanpa akhir yang dilakukan oleh kode-kode, seperti di alamiah". Gagasan desain generatif dengan morfogenesis digital sangat terikat satu sama lain, sebab memiliki terjemahan sebagai 'kelahiran bentuk' yang sehubungan dengan teknologi dan teknik yang muncul. Sedangkan pada pernyataan dari Branko Kolarevic (2003) terkait morfogenesis digital merupakan "Hubungan yang dapat diprediksi antara desain dan representasi ditinggalkan demi kompleksitas yang dihasilkan secara komputasi. Terdapat beberapa kriteria model desain yang dapat ditransformasikan yaitu:

1. Bentuk transformasi yang konsisten;

2. Memiliki sifat berkesinambungan;

3. Bentuk yang dinamis menggantikan norma-norma statis dari proses konvensional;

4. Bentuk geometri lengkung kompleks seperti geometri Euclidean dari bentuk planar dan bentuk silinder, bola atau kerucut;

5. Terdapatnya kisi-kisi, pengulangan, dan simetri sebab variabilitas yang tidak terbatas menjadi layaknya seperti modularitas."

Abbas (2014) menjelaskan terkait sistem generatif, "Dengan sistem desain generatif, generasi sejumlah besar alternatif desain memperluas ruang pencarian desain. Hal ini menyebabkan masalah dalam eksplorasi alternatif desain". Manajemen ruang pencarian desain yang tidak efisien dapat menempuh dialog antara desainer dan objek desain yang menghalangi navigasi ruang desain seorang desainer.

Menurut Foster + Partners dalam tulisan Adnan \& Yunus (2012) menyatakan tentang arsitektur adalah pengalaman interior dan eksterior. Bagaimana cara seseorang bergerak melaui sebuah bangunan, baik menaiki tangga atau perjalanan urutan ruang dengan mencari rute untuk ditelusuri melalui kota dengan jalan-jalan, alun-alun, dan jembatan. Tata ruang Great Court terdapat ruang baca berbentuk melingkar dibatasi oleh dua tangga lebar pada kanan kirinya. Bentuk atap yang melengkung mengundang pengunjung untuk naik dan menjelajahi ketinggian dan volume ruang. Dalam menaiki anak tangga menghasilkan sensasi berbeda yang dialami sekaligus dapat menyaksikan aktivitas di sekitar area pameran, kafe, dan toko souvenir di lantai dasar dari ketinggian yang berbeda.

\section{Konstruksi Kontemporer}

Konstruksi kontemporer adalah bangunan yang menggunakan konstruksi kontemporer. Arsitektur bangunan berkonstruksi kontemporer merupakan bentuk sebuah karya arsitektur yang sedang terwujud di masa sekarang dan di masa yang akan datang. Arsitektur bangunan berkonstruksi kontemporer merupakan salah satu pendekatan dalam merancang secara universal. Arsitektur kontemporer merupakan suatu style atau gaya aliran arsitektur yang muncul pada akhir abad 20 sampai dengan saat ini, memiliki tampilan sesuatu yang berbeda dengan menampilkan kualitas tertentu terpenting dari segi penggunaan teknologi serta kebebasan dalam menampilkan suatu gaya dalam arsitektur (Hidayatullah, 2018). 
Arsitektur kontemporer merupakan gaya arsitektur yang didasari oleh semangat perubahan berasal dari revolusi industri di Inggris. Revolusi Industri tersebut menyebabkan munculnya tipologi bentuk bangunan baru yang berbeda dari fungsi serta bentuk bangunan pada umumnya. Revolusi industri tidak hanya memunculkan tipologi baru, tetapi juga mengakibatkan adanya penggunaan material dan teknik baru dalam arsitektur. Arsitektur kontemporer muncul karena kebutuhan terhadap gaya baru pada awal tahun 1920-an, kemudian terus berkembang ke era art dan craft. Pada era tersebut dimulainya situasi masyarakat yang mulai jenuh dengan fabrikasi sehingga melakukan gerakan sosial yang disebut craftsmanship (keahlian) (Desi, Mauliani, \& Sari, 2019).

Gaya kontemporer pada dasarnya memiliki pengertian yaitu gaya desain yang sedang terjadi dan diproduksi di masa sekarang. Gaya kontemporer memiliki gaya arsitektur yang lebih dinamis, sehingga tidak terikat oleh suatu era tertentu. Arsitektur kontemporer merupakan salah satu pendekatan dalam merancang secara internasional sehingga banyak para ahli yang mengemukakan pendapat mengenai definisi dari 3. Konnemann (World of Contemporary Architecture XX) pada kutipan Hidayatullah (2018), Arsitektur kontemporer adalah gaya arsitektur yang bertujuan untuk memberikan contoh suatu kualitas tertentu terutama dari segi kemajuan teknologi dan juga kebebasan dalam mengekspresikan suatu gaya arsitektur.

Schirmbeck (1993) menjelaskan bahwa arsitektur kontemporer berkembang dari sebuah pemikiran bahwa arsitektur harus mampu memperoleh sasaran dan pemecahan bagi arsitektur di hari esok dan pada kondisi masa kini, dan terdapat beberapa prinsip dalam arsitektur kontemporer yaitu:

1. Memiliki bangunan yang kokoh,

2. Terdapat gubahan masa yang berbentuk ekspresif dan dinamis,

3. Terdapatnya sifat terbuka pada konsep ruang,

4. Adanya kenyamanan yang hakiki,

5. Keharmonisan ruang yang menyatu dengan ruang luar,

6. Eksplorasi elemen area lanskap yang berstruktur.

\section{Metode Penelitian}

Penelitian ini menggunakan metode deskriptif-kualitatif, dengan cara mengklasifikasi mengategorikan kriteria berdasarkan analisis terhadap landasan teori yang digunakan sebagai acuan pendekatan yang digunakan dalam penelitian. Penelitian ini menggunakan metode kualitatif karena jenis penelitian dan temuan-temuannya tidak didapatkan melaui prosedur statistik atau bentuk hitungan lainnya. Adapun jenis pendekatan penelitian ini adalah deskriptif. Penelitian deskriptif merupakan penelitian yang digunakan untuk eksplorasi dan klarifikasi mengenai suatu fenomena dalam pemecahan sebuah masalah yang diteliti berdasarkan data-data.

Metode pada penelitian ini dengan cara menganalisis studi kasus terhadap prinsip yang ditentukan dari desain generatif. Studi kasus bangunan Brithis Museum Great Court di London, United Kingdom. Penelitian ini difokuskan untuk mengkaji mengenai bentuk bangunan studi kasus berdasarkan konsep prinsip generatif. 


\section{Hasil dan Pembahasan}

Bangunan Great Court yang didirikan pada pertengahan abad ke-19 pada bagian atap dirancang oleh Foster and Partners, Great Court adalah ruang seluas dua hektar yang dikelilingi oleh atap kaca yang spektakuler dengan ruang baca yang terkenal di dunia di tengahnya. Bangunan dibuat berdasarkan pada konsep Norman Foster untuk atap Reichstag gedung parlemen Jerman baru di Berlin. Bangunan memiliki sebuah jalan spiral yang berbentuk kubah kaca di atas ruang debat sebagai elemen yang sangat sukses dalam menjadikan politik sebagai proses publik (Kolarevic, 2003). Pengerjaan atap kaca dan baja Great Court yang megah - terbuat dari 3.212 panel kaca (tidak ada dua yang sama) - dimulai pada bulan September 1999. Bangunan memiliki atap kaca berlapis dari skema ini untuk menentukan hirarki, dan solusi yang dihasilkan dioptimalkan berdasarkan persyaratan geometris dan struktural. Dalam upaya memahami prinsip-prinsip arsitektur generatif pada dunia konstruksi kontemporer, dengan studi kasus Great Court, diperlukan pemahaman tentang hal-hal berikut:
a. Bentuk dan gubahan masa
b. Tata ruang dan sirkulasi
c. Tampak dan fasad bangunan
d. Struktur dan konstruksi bangunan

\section{a. Bentuk dan Gubahan Masa}

Bentuk yang rumit terletak pada pembentukan struktur rangka atap yang melengkung, serta adanya pusat bangunan berbentuk lingkaran yang dipadukan pada bentuk bangunan utama bidang persegi. Prinsip kompleks pada bangunan terlihat dari bentuk bangunan dengan penataan yang berirama terhadap sekeliling atap kubah pada bangunan (Gambar 3).

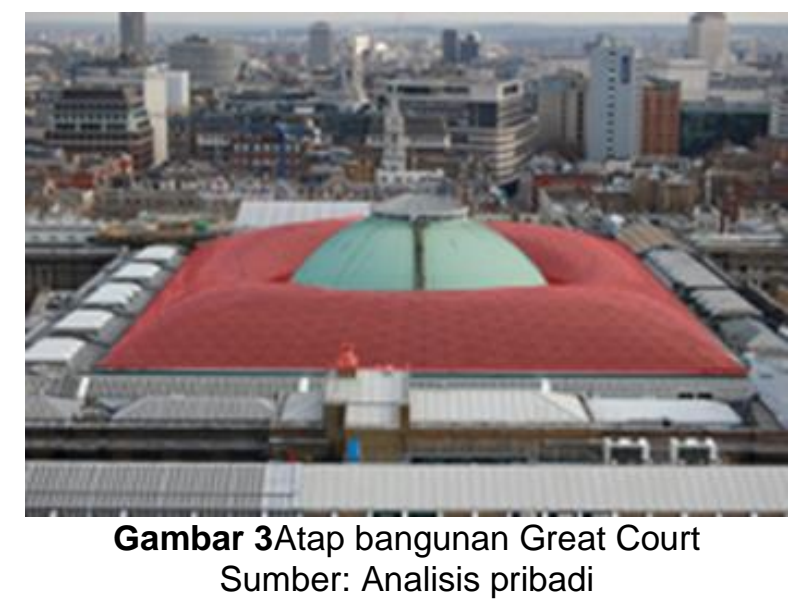

Bentuk dan gubahan masa memiliki sifat unity dari adanya bentukan bangunan yang merupakan bentuk persegi. Sedangkan pada bagian atap utama dengan atap di sekeliling bangunan tidak memiliki kesamaan, sebab atap utama menggunakan bentuk melengkung dan berbentuk kubah. Tetapi atap penutup terhadap ruang baca memiliki bentuk melengkung dan warna hijau muda, sehingga memiliki bentuk yang unity dengan bentuk struktur atap pada ruang halaman (Gambar 4). Bentuk dan gubahan masa pada 
bangunan Great Court memiliki bentuk yang tidak dinamis, melainkan dengan bentuk statis.

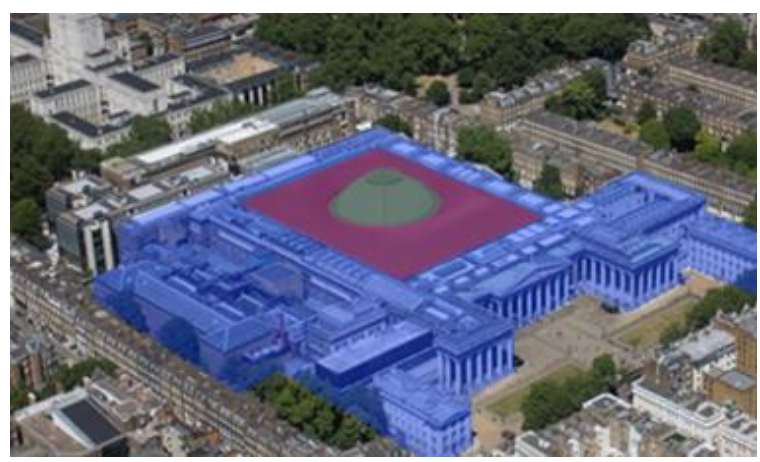

Gambar 4Bentuk bangunan secara keseluruhan Sumber: Analisis pribadi

Bentuk dan gubahan masa bangunan Great Court pada bentuk bangunan utama tidak memiliki ciri lengkung, sebab bangunan pada dasarnya memiliki bentuk persegi. Tetapi pada bagian struktur atap bangunan yang memiliki ciri bentuk geometri lengkung yang kompleks. Bentuk kelengkungan tersebut sangat penting terhadap struktural sebab memberikan dorongan untuk keseimbangan tegangan pada balok tepi bangunan (Gambar 5).

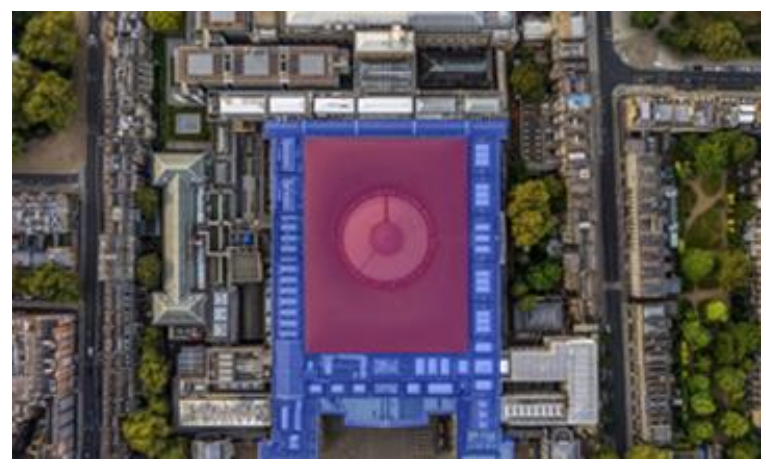

Gambar 5Ciri lengkung pada bangunan Sumber: Analisis pribadi

Bentuk gubahan masa terhadap pengulangan dan simetri terlihat pada bentuk atap yang ditentukan oleh permukaan simpul kisi-kisi baja yang dihubungkan menjadi bentuk lengkung torus. Pengulangan struktural dengan satu panel datar dari kaca ganda untuk setiap segitiga dari grid struktural. Prinsip simetri pada gubahan masa dapat dilihat pada bentuk masa memiliki bentuk yang sama, jika dilihat dari garis tengah pada bangunan (Gambar 6). 


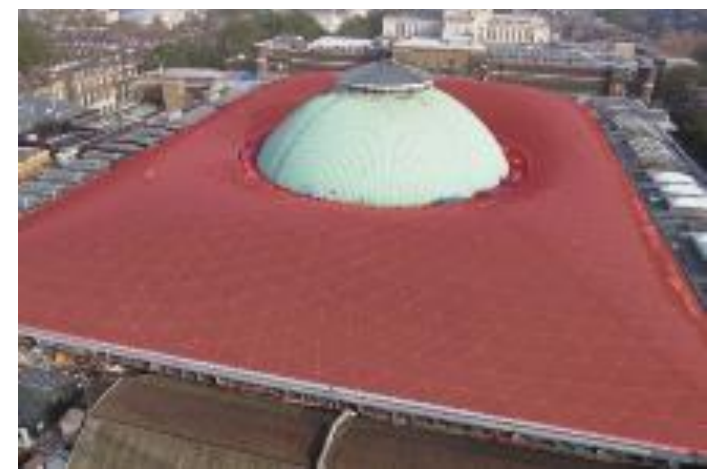

Gambar 6Bentuk atap dari pengulangan Sumber: Analisis pribadi

\section{b. Tata Ruang dan Sirkulasi}

Tata ruang dan sirkulasi pada bangunan Great Court terdapat ruang baca di tengah dengan bentuk melingkar dibatasi oleh dua tangga lebar, yang dikelilingi oleh bangunan utama berbentuk persegi panjang membuat banyaknya ruang yang harus mengikuti bentuk pada ruang baca yang melingkar. Bentuk yang rumit terhadap penataan ruang menciptakan adanya ruang pasif pada interior. Tetapi dengan adanya halaman yang luas menjadikan ruang pasif teralihkan, pada interior ruang yang membuat pengunjung untuk menjelajah ke seluruh bangunan (Gambar 7). Tata ruang dan sirkulasi pada Great Court terhadap prinsip unity, memiliki bentuk yang saling berkesinambungan dari bentuk dan penataan denah yang terlihat. Meskipun memiliki bentuk masa utama yang persegi dengan penataan ruang yang melingkar, tetapi bentuk antar ruang memiliki keterhubungan ruang dalam penyesuaian bentuk denah pada ruang baca yang berbentuk melingkar (Gambar 7).
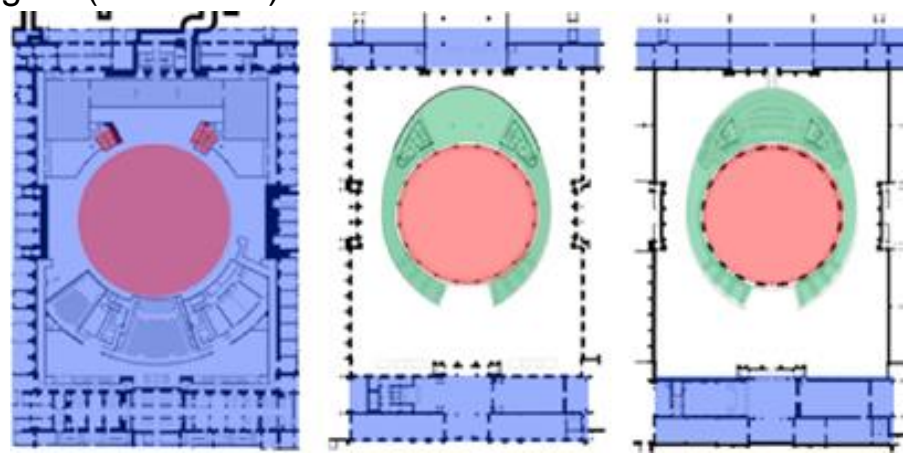

Gambar 7Denah Great Court

Sumber: Analisis pribadi

Tata ruang dan sirkulasi pada bangunan Great Court memiliki prinsip bentuk yang dinamis, karena ruangan dapat selalu berkembang waktu demi waktu terhadap fungsi ruang. Dinamis terhadap tata ruang mengacu pada kondisi objek yang mewadahi kegiatan-kegiatan mobilitas tinggi. Bentukan denah dan tata ruang bangunan yang berupa gabungan bentuk-bentuk geometri yang mencerminkan prinsip dinamis. Tata ruang dan sirkulasi terhadap bentuk geometri lengkung yang kompleks terlihat pada bentuk denah ruang baca yang dihadirkan dengan berbentuk lingkaran. Bentuk ruang baca yang melingkar dipadukan dengan tangga yang melingkari ruang menciptakan sirkulasi penataan ruang yang kompleks (Gambar 8 dan Gambar 9). 

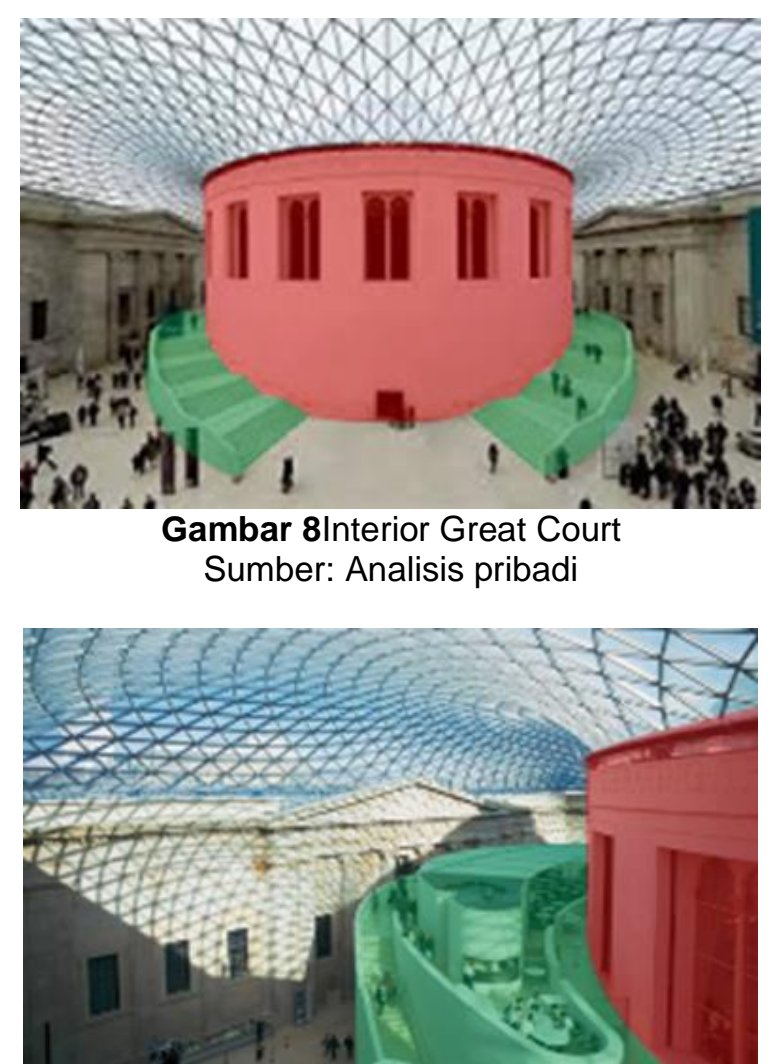

Gambar 9Geometri lengkung pada tangga dan ruang baca Sumber: Analisis pribadi

Bentuk pengulangan dan simetri pada tata ruang dan sirkulasi pada bentuk dan penataan denah yang berbentuk lingkaran dengan bagian selasar pada sisi bangunan utama. Jika denah di potong menjadi dua bagian maka terdapat kesamaan atau sejajar antara sisi satu dengan sisi yang lainnya.

\section{c. Tampak dan Fasad Bangunan}

Bangunan memiliki bentuk yang rumit sebab merupakan bangunan yang di dirikan pada pertengahan abad ke -19 dengan bentuk bangunan seperti kebangkitan Yunani. Bangunan rumit sebab merupakan bangunan symbol kebesaran Kerajaan Inggris yang dipugarkan dengan gaya Prancis dan memakai struktur konstruksi klasik. Bentuk yang rumit dengan melihat dari banyaknya pemakaian kolom pada tampak bangunan dan penggunaan struktur yang besar, meskipun bangunan rumit tetapi memperlihatkan ke kompleksitas yang ditampilkan pada bangunan dengan kekokohannya (Gambar 10).

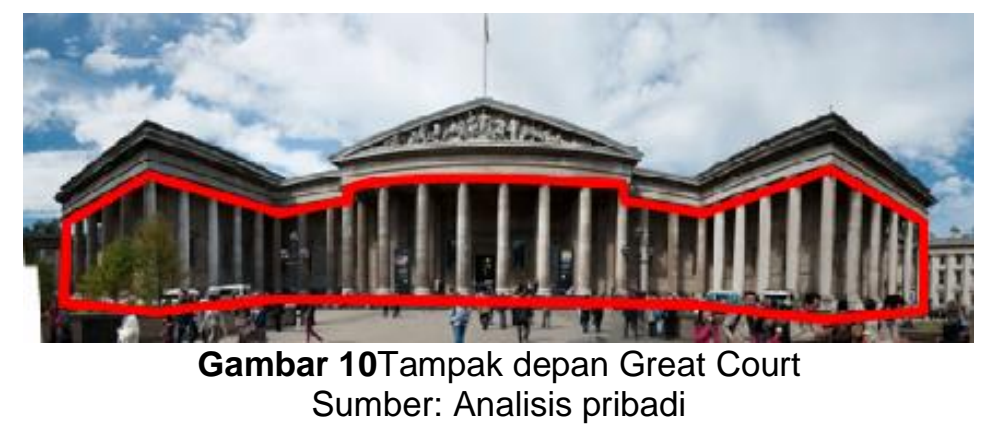

Bentuk unity yang saling berkesinambungan pada tampak dan fasad bangunan Great 」AD-Vol.02/No.02, Desember 2021| 149 
Court terlihat dari adanya tampilan fasad bangunan utama dengan interior bangunan yang menampilkan elemen klasik Yunani serta warna yang mendominasi yaitu abu-abu (Gambar 11). Tampak dan fasad pada bangunan Great Court memiliki bentuk yang tidak dinamis, melainkan dengan bentuk statis. Sebab bentuk fasad bangunan tidak memiliki pergerakan. Bangunan utama tidak memiliki ciri geometri lengkung yang kompleks. Tetapi pada ruang baca memiliki ciri lengkung yang dihubungkan dengan struktur atap lengkung menutupi ruang halaman pada bangunan.

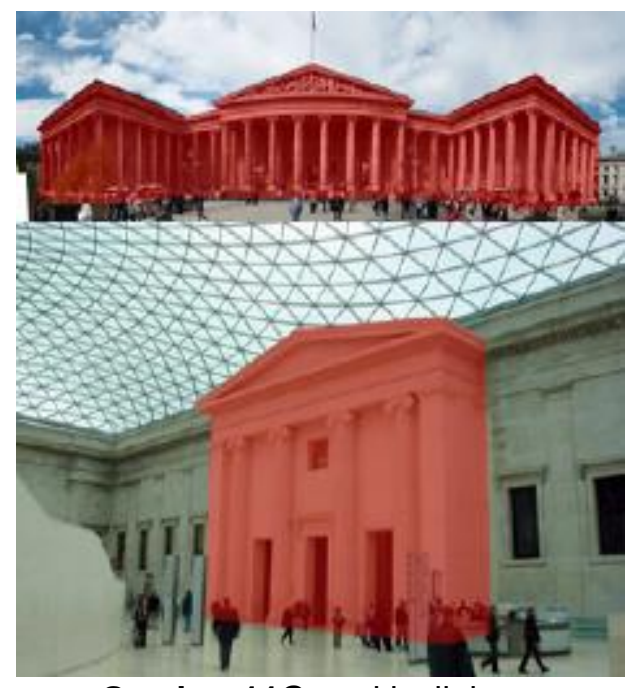

\section{Gambar 11Gaya klasik kuno}

Sumber: Analisis pribadi

Pada bagian fasad dan tampak bangunan Great Court memiliki ciri pengulangan dan simetri terhadap bentuk yang memiliki kesamaan. Bentuk simetri terlihat pada pintu masuk bangunan yang memiliki proporsi yang seimbang antara sisi kanan dan kirinya, begitu pula pada bagian atap.

\section{d. Struktur dan Konstruksi Bangunan}

Bentuk kerumitan pada struktur bangunan terlihat pada pemakaian struktur grid triangulasi pada kekakuan struktural yang dibentuk menghasilkan diskontinuitas (ketidaksinambungan), terhadap arah diagonal yang dihasilkan dengan menggabungkan titik-titik grid pada atap bangunan. Diskontinuitas tersebut dapat dihilangkan dan menjadi bentuk kompleks dengan mengendurkan grid untuk mendapatkan proses relaksasi pada rancangan sehingga membentuk permukaan torus yang diinginkan pada struktur atap kaca (Gambar 12).

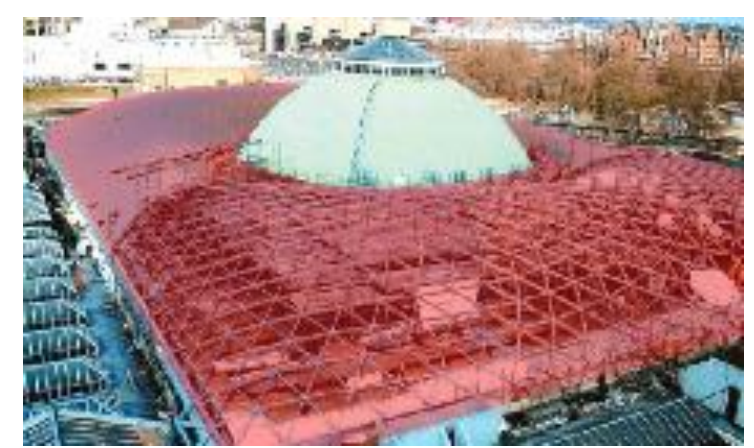

Gambar 12 Konstruksi atap Great Court 


\section{Sumber: Analisis pribadi}

Bentuk unity pada bangunan Great Court terhadap struktur pada bagian atap kaca yang dibentuk dengan sudut triangulasi, dengan bentuk planar rangka ruang yang terbuat dari batang baja disatukan pada sudut konektor. Bentuk transisi melingkar pada ruang baca pada bentuk segi empat bangunan museum di sekitarnya terhadap bentuk atap, menghadirkan sebuah desain dengan geometri melengkung yang saling berkesinambungan. Konstruksi atap tersebut membuat bangunan menjadi kesatuan antara bentuk yang kotak dengan bentuk melingkar (Gambar 13).

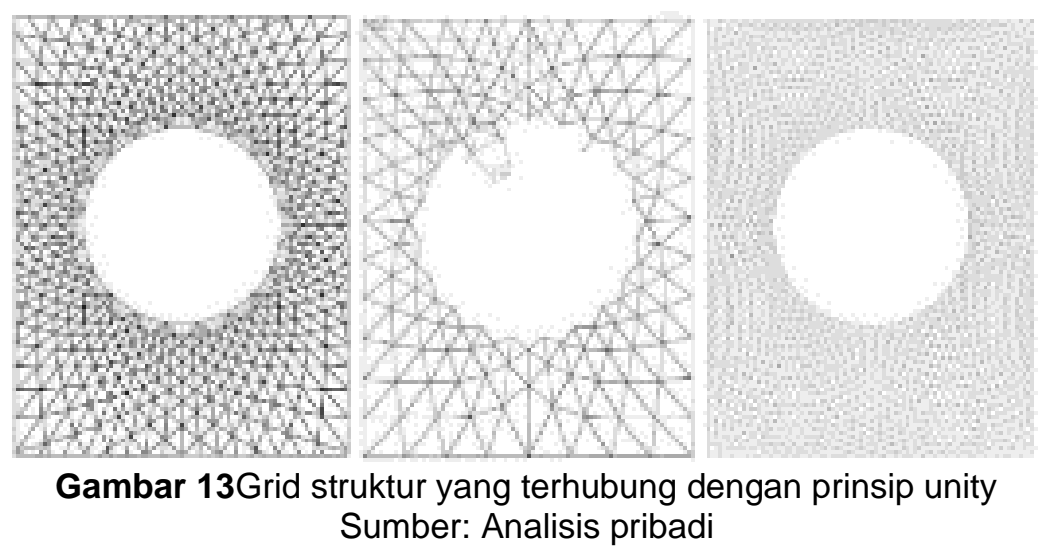

Struktur dan konstruksi pada bangunan Great Court memiliki bentuk yang dinamis. Bentuk dinamis dapat dilihat dari pembentukan struktur atap pada ruang halaman pada bangunan. Struktur atap bangunan memiliki bentukan lengkung fleksibel, dan adanya ruang tengah membentuk konstruksi dengan bentuk melingkar. Struktur yang memiliki ciri lengkung yang kompleks terdapat pada struktur atap rangka ruang pada bangunan yang memiliki bentuk permukaan torus. Dengan bentuk geometri kompleks yang didasarkan pada tambalan bentuk struktur torus yang terhubung dengan sempurna bertransisi satu sama lain untuk mendekati permukaan lengkung kompleks (Gambar 14).

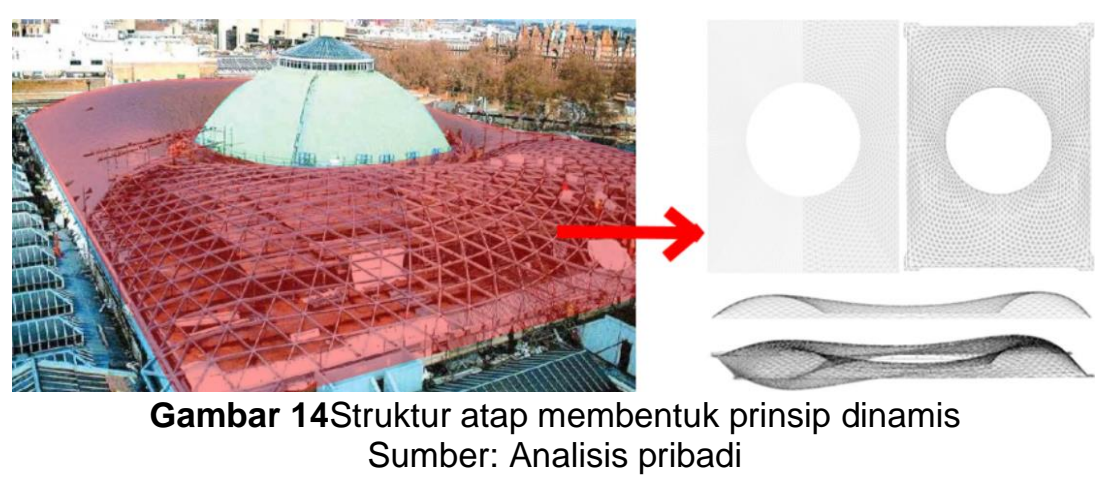

Bentuk pengulangan pada struktur terlihat pada konstruksi bagian atap kaca yang menggunakan planar kerangka ruang berbentuk segitiga, dibuat dari batang baja yang disatukan pada sudut konektor berbentuk bintang berkaki enam. Struktur atap juga memiliki ciri simetri sebab bentuk yang sama atau sejajar antara sisi yang satu dengan sisi yang lainnya. 


\section{Kesimpulan}

Berdasarkan hasil dan pembahasan yang telah dilakukan terhadap bangunan Great Court didapatkan kesimpulan, bahwa bangunan hanya menerapkan beberapa prinsip-prinsip dari penerapan metode konsep generatif, antara lain:

1. Bentuk yang rumit dan kompleks;

2. Bentuk yang unity, bagian satu dengan yang lain saling berkesinambungan;

3. Bentuk pengulangan dan simetri.

Dari ciri-ciri generatif tersebut terdapat pada elemen yang di analisis, yaitu:

1. Bentuk dan gubahan masa

2. Tata ruang dan sirkulasi

3. Tampak dan fasad bangunan

4. Struktur dan konstruksi bangunan

Sehingga mendapatkan hasil penelitian bahwa kelima prinsip-prinsip konsep generatif, terdapat dua prinsip yang tidak ada pada bangunan Great Court yaitu bentuk yang dinamis dan geometri lengkung yang kompleks. Kedua prinsip tersebut tidak adanya pada elemen bentuk gubahan masa dan tampak fasad bangunan, sebab bangunan memiliki bentuk yang statis dan bentuk utama bangunan berbentuk persegi karena prinsip lengkung hanya terdapat pada bentuk atap pada bangunan Great Court.

Great Court merupakan bangunan hasil pengembangan dari sebuah desain, atau bangunan yang di reuse dengan prinsip digitalisasi modern arsitektur generatif. Bangunan memiliki prinsip arsitektur generatif terdapat di elemen struktur penambah pada bangunan, seperti struktur batang yang digunakan sebagai struktur atap pada bangunan.

\section{Ucapan Terimakasih}

Terimakasih kepada Program Studi Arsitektur Universitas Muhammadiyah Jakarta yang sudah membiayai penelitian tentang, Kajian Konsep Generatif Dalam Dunia Konstruksi Kontemporer Pada Bangunan Great Court di London, United Kingdom, ini lewat Hibah Penelitian Mahasiswa dengan nomor kontrak 007/PKKM-ARS/UMJ/VIII/2021.Terimakasih juga diberikan kepada berbagai pihak yang telah membantu dan memberikan bantuan dalam menyelesaikan penelitian, yang tidak dapat disebutkan satu persatu.

\section{Daftar Pustaka}

Abbas, G. M. (2014, Mei). Visual Structures for Generative Design Search Spaces. Retrieved from Open.metu.edu.tr: https://open.metu.edu.tr/handle/11511/23622

Adnan, F., \& Yunus, R. M. (2012). The Influence of Curvilinear Architectural Forms on Environment-Behaviour. rocedia-Social and Behavioral Sciences 49, 341-349.

Agkathidis, A. (2015). Generative Design Form + Technique. London: Laurence King Publishing Ltd. 
Aqli, W. (2015). Digitalisasi Logo Menjadi Elemen Estetis Bangunan Menggunakan Pemodelan Parametrik - Studi Kasus Logo Muhammadiyah. Simposium Nasional Teknologi Terapan (SNTT), A-27 - A-35.

Artha, C. A. (2011). Eksplorasi Desain Menggunakan Generative Algorithm Pada Perancangan Fasad Kampus ATMI Cikarang. Tesis Jurusan Arsitektur - Institut Teknologi Bandung.

Atthaillah. (2014). Arsitektur Parametrik dengan Rhinoceros dan Grasshopper: Kajian Workflow dari Desain, Fabrikasi hingga Hitunngan Kebutuhan Material. Jurnal Arsitekno, 1-13.

Desi, H., Mauliani, L., \& Sari, Y. (2019). Penerapan Arsitektur Kontemporer Pada Sekolah Model dan Mode Muslim Dian Pelangi. PURWARUPA Jurnal Arsitektur 2(2), 31-36.

Hidayatullah, R. (2018, Januari 15). Evaluasi Penerapan Karakteristik Arsitektur Kontemporer (Studi Kasus: Design Masjid Ontowiryo Di Purworejo, Jawa Tengah). Retrieved from DSpace Repository: https://dspace.uii.ac.id/handle/123456789/6143

Kaarwan, I. (2021, Februari 19). Evolution of Generative Architecture. Retrieved from Evolution of

https://www.instagram.com/p/CLd3AkjJq0i/?utm_medium=copy_link

Khabazi, Z. (2010). Generative Algorithms using Grasshopper. Morphogenesism.

Khidmat, R. P., Ulum, M. S., Lestari, D. E., \& Fukuda, H. (2020). Optimasi Komponen Fasad Menggunakan Generative Algorithm Studi kasus: ITERA Lampung. Jurnal Arsitektur, 1928.

Kolarevic, B. (2003). Architecture in the Digitalage: Design and Manufacturing. London: Taylor \& Francis.

Krish, S. (2011). A Practical Generative Design Method. Computer-Aided Design, 88-100.

Schrimbeck, E. (1993). GAGASAN, BENTUK dan ARSITEKTUR Prinsip-Prinsip Perancangan dalam Arsitektur Kontemporer (kedua ed.). Bandung: Intermatra.

Sepehr, A., Goudling, J. S., Rahimian, F. P., \& Ganah, A. (2013). INTEGRATION OF BIM AND GENERATIVE DESIGN TO EXPLOIT AEC CONCEPTUAL DESIGN INNOVATION. Information Technology in Construction, 350-359.

Snyder., J. C., \& Catanese, A. J. (1991). Pengantar Arsitektur. Jakarta: Erlangga.

Soddu, C. (1994). The design of Morphogenesis. An experimental research about the logikal prosedures in design processes. Demetra Magazine, vo 